\title{
Yearly Electrical Energy Assessment of a Photovoltaic Platform/Geothermal Heat Pump Prosumer
}

\author{
Macedon Moldovan*(D), Bogdan-Gabriel Burduhos and Ion Visa
}

Citation: Moldovan, $\mathrm{M}$

Burduhos, B.-G.; Visa, I. Yearly

Electrical Energy Assessment of a

Photovoltaic Platform/Geothermal Heat Pump Prosumer. Energies 2021, 14, 3776. https://doi.org/10.3390/ en14133776

Academic Editors: Jurgen Werner and James Conolly

Received: 5 May 2021

Accepted: 17 June 2021

Published: 23 June 2021

Publisher's Note: MDPI stays neutral with regard to jurisdictional claims in published maps and institutional affiliations.

Renewable Energy Systems and Recycling Research Centre, Transilvania University of Brasov, 500036 Brașov, Romania; bogdan.burduhos@unitbv.ro (B.-G.B.); visaion@unitbv.ro (I.V.)

* Correspondence: macedon.moldovan@unitbv.ro; Tel.: +40-740-300-804

\begin{abstract}
Romania introduced in 2018 an amendment to the national law 220/2008 by including the Prosumer concept that allows investors in grid-connected photovoltaic systems with a capacity up to $27 \mathrm{kWp}$ to receive a feed in tariff for the electricity delivered to the grid representing approximatively one third of the price paid when the electricity is consumed from the grid. Thus, the challenge is to use as much as possible the photovoltaic power when it is produced. A methodology is developed to evaluate how much of the electrical energy output of a grid-connected photovoltaic platform is used by a geothermal heat pump for space heating in a building. A numerical simulation is performed in Trnsys17 based on locally measured meteorological parameters over a period of one entire year. A case study is presented for which the characteristics of the building, of the heat pump system and of the photovoltaic system are described and integrated into the transient simulation environment. The numerical results are comparatively presented and discussed along with experimental data for sunny days in cold season. For the analysed case study, the self-consumption is $16 \%$, significantly lower than the yearly coverage degree of $70 \%$. Further research can be done to increase the self-consumption.
\end{abstract}

Keywords: renewable based energy mix; heat pump; photovoltaic system; prosumer; self-consumption

\section{Introduction}

The world total energy consumption is continuously growing as reported by International Energy Agency [1] with an average yearly rate of 1.5\% over the period 2013-2018. According to the same study, 19\% of the total energy consumption is represented by the electricity consumption, the industry sector being the main responsible (42\%) followed by the residential sector $(27 \%)$ and by the commercial and public services sector $(22 \%)$.

Photovoltaic systems are ones of the most promising technologies converting the solar energy into clean electrical energy. According to International Energy Agency [2] an exponential growth was registered in the installed capacity of photovoltaic systems with a yearly average increase of 32\% in the period 2013-2018. The photovoltaic technology is nowadays successfully applied in a large range of applications, from small size installations (a few $\mathrm{kWp}$ ) to very big ones (tens or hundreds of $\mathrm{MWp}$ ). The levelized cost of photovoltaic electricity continuously declined, by 48\% between 2014 and 2018, reaching a global weighted-average of $0.068 \mathrm{USD} / \mathrm{kWh}$ in 2019 [3]. Even lower values ranging between 0.03 and $0.045 \mathrm{EUR} / \mathrm{kWh}$, and 0.05 and $0.075 \mathrm{EUR} / \mathrm{kWh}$ were reported for Spain and UK respectively in 2021 [4].

A very efficient way to use the electrical energy for space heating is by using heat pumps that have smaller power consumption than any other electricity driven heating system. According to the European Heat Pump Association [5] the European heat pump stock reached 13.27 million units in 2019 that generated 158 TWh of renewable energy saving $40.5 \mathrm{Mt}$ of $\mathrm{CO}_{2}$.

Both technologies, photovoltaic and heat pump, are good candidates for the sustainable development of new buildings and refurbishment of the existing ones, significantly 
contributing to the environmental objectives of the European Union established through the recently launched European Green Deal [6].

Usually, the photovoltaic systems and the heat pump systems are separately designed and implemented in the built environment. The main objective targeted in the design process of a photovoltaic system is to maximize its yearly electrical energy output. In the case of fixed photovoltaic platforms, this is obtained by optimizing the tilt angle of the photovoltaic modules in correlation with the characteristics of the implementation site. Thus, due to larger amount of solar energy during summer than winter, the tilt angle will be close to the complement of the solar elevation angle at summer solstice noon to maximize the received solar energy in this period [7]. This way of setting the tilt angle negatively affects the amount of the solar energy received during the winter days when the electrical energy demand of a heat pump system is higher. A heat pump system is designed to cover the thermal loses of a building for the lowest outdoor air temperature. From this requirement results the maximum thermal power of the heat pump. Due to the main advantage of the geothermal energy (its daily and even seasonal invariance) the storage capacity of the thermal energy is rather low, without the possibility to capitalize on the surplus of electricity obtained during sunny winter days.

The energy mixes consisting of photovoltaic platforms and heat pump systems have only recently begun to be studied, after the price of the photovoltaic systems started dropping in 2010 [5].

One of the first reported studies on photovoltaic-heat pump systems was published by Kugle et al. in 1984 [8]. The output of two photovoltaic arrays, rated at 8 and $6.4 \mathrm{kWp}$, was used $54.6 \%$ by the residence while the remaining $45.4 \%$ was fed into the grid indicating that the heat pump and the photovoltaic arrays were not properly sized with each other [8]. Since then, several papers addressed this topic of solar photovoltaic assisted heat pumps, mainly considering photovoltaic-thermal (PVT) systems where the back surface of the photovoltaic modules accommodates a thermal collector working as evaporator for the heat pump. This solution, besides the thermal energy supplied to the building, helps to reduce the PVT module temperature increasing thus its efficiency and therefore its energy output. However, this paper address the self-consumption issue of the photovoltaic-heat pump systems for which a literature review is further presented.

Fraga et al. [9] performed a comparative analysis of combined heat pump and photovoltaic systems where the electricity production of the photovoltaic system is used with priority in the form of self-consumption by the heat pump system. A high discrepancy was found between the annual self-consumption calculated based on hourly and daily match. Using hourly match, the self-consumption between 33 and 59\% resulted, dropping with about $50 \%$ of the value calculated with daily match ranging between 57 and $96 \%$.

Franco and Fantozzi [10] analysed a ground source heat pump-photovoltaic system implemented in Pisa, Italy to provide thermal and electrical energy for a typical residential house. The heat pump has an installed thermal power of $14.4 \mathrm{~kW}$ and a nominal electric power of $3.8 \mathrm{~kW}$ matched with the installed power of the photovoltaic system $(3.74 \mathrm{kWp})$. The results show that this design approach maximizes the self-consumption during winter months up to $35.6 \%$ but does not allow the system to operate independent of the grid in the heating period. A possible solution to improve the energy efficiency consists of sizing the heat pump capacity at $80 \%$ of the required nominal power.

Nizetic et al. [11,12] experimentally and numerically evaluated a hybrid energy system consisting of a $1.8 \mathrm{kWp}$ off-grid photovoltaic system and a $3.7 \mathrm{~kW}$ heating capacity heat pump. The electrical energy output of the photovoltaic platform is partly used by the heat pump and the excess is stored in batteries. Thus, the entire electricity is finally used by the heat pump. The results showed high seasonal coefficient of performance values of this type of energy system implemented in countries with mild climates.

Perkovic et al. [13] have investigated a hypothetical group of 20 residential houses, each with a surface of $250 \mathrm{~m}^{2}$, located in Zagreb, Croatia, in terms of thermal energy demand for space heating and cooling provided by a heat pump system coupled to a shallow 
geothermal reservoir, and of electrical energy required for the appliances, heat pumps, hydraulic pumps and electric heaters. Four scenarios were simulated using RES2GEO (Renewable Energy Sources to Geothermal) model on a 20-year horizon. The excess electricity produced by the photovoltaic system is used to regenerate the geothermal reservoir with positive effects on the heat pump system performance and levelized cost of energy.

Reda et al. [14] assessed two promising solar assisted heat pump systems for an office building in Finland. One system consists of solar thermal collectors and an absorption heat pump, while the second relies on a photovoltaic driven air source heat pump. For the second solution, dynamic energy simulations were performed using real on-site measurements as inputs. The photovoltaic driven heat pump system has proved to be more feasible but its self-consumption (15\%) is lower than that of the solar thermal assisted absorption heat pump (25\%).

The ideal combination of photovoltaic/heat pump systems is when the thermal demand matches the photovoltaic power output (e.g., cold and sunny winter days when the electrical energy may be directly used to drive the heat pump for space heating without any need for storage devices). This situation does not occur very often during the winter time. Therefore, researchers further evaluated various methods to increase the self-consumption in the case of photovoltaic/heat pump systems.

Thygesen and Karlsson [15] proposed a novel weather forecast controller for a photovoltaic/heat pump system aiming to increase the self-consumption of the generated electricity by solar photovoltaic modules. The results show that the controller is not economically feasible since the increment in the self-consumption was not covering its cost.

One solution to increase both the self-consumption of the photovoltaic-heat pump systems and its economic/environmental benefits consists of combining it with battery storage as shown by Litjens et al. [16]. The results demonstrated that the photovoltaic system alone can provide around $19 \%$ of the ground source heat pump electrical energy demand while with batteries this share can be enhanced by $53 \%$.

Facci et al. [17] proposed a thermal energy storage system to increase the feasibility of photovoltaic-heat pump systems. The outcomes of this study show that the energy costs are reduced up to $41 \%$ while $\mathrm{CO}_{2}$ emissions are mitigated with $73 \%$ when such a system is implemented instead of natural gas boilers. Also, if the self-consumption of the on-site produced electrical energy is adequately promoted, the feasibility of the photovoltaic system is increased, becoming competitive without requiring specific subsidies such as feed in tariffs, etc.

Rinaldi et al. [18] assessed the optimal investments in photovoltaic and heat pump systems to decarbonize the space heating in Swiss residential buildings under different energy retrofitting scenarios. The results show that the scenario with a heat pump supplying the entire thermal energy demand appears to be feasible and does not only decarbonize heat but also allows the shift of the peak energy demand from night to midday. Thus, the self-consumption of the on-site generated photovoltaic electricity increases, resulting in larger and more feasible photovoltaic development.

Hirvonen et al. [19] evaluated the economic potential of different photovoltaic-heat pump systems used for domestic hot water and space heating in Nordic countries. The results show yearly coverage degree ranging between 49 and 100\%, and self-consumption between 9 and $28 \%$ for photovoltaic system of 1,3 and $5 \mathrm{kWp}$ and thermal storage capacities of 0,300 and $1000 \mathrm{~L}$.

Beck et al. [20] developed a mixed integer linear programing model for the optimal photovoltaic-heat pump system configuration and operation. The model was applied under different scenarios and the results demonstrated that the sizing of the heat pump is strongly influenced by the scenario assumptions, while the dimensioning of PV is hardly dependent on the electrical load profiles.

Becoming a prosumer [21] with lowest energy costs and maximal self-consumption is nowadays an intensely studied aspect with benefits both for the end-user and the local electrical energy distributor [22]. Different types of prosumers are analysed in literature, 
with different production, storage and consumption technologies, which depend on the consumer type and on the installation location.

As such, at low latitude angles like South Africa a simple technological solution includes the photovoltaic system with battery storage capabilities. This is able to assure a total daily cost reduction of $62.71 \%$ in summer and $68.99 \%$ in winter for residential prosumers and of $81.31 \%$ in summer and $31.69 \%$ in winter for commercial prosumers [23]. These values translate into the following break-even intervals: 16.35 years for residential prosumers and 5.3 years for commercial prosumers.

More advanced technological solutions like energy sharing among community members, thermal storage of excess photovoltaic energy and using electrical vehicles for storing electrical energy are analysed at Northern European latitudes, in Sweden [24]. The authors indicate that if energy is shared among community members in a residential building cluster this could generate self-consumption ratios as high as 77\%. If thermal energy storage and suitable control for generating heat using photovoltaic excess production is used, this can increase the photovoltaic size and the self-consumption rate up to $79.4 \%$. Further on, if electric vehicles are also added to the system this can increase the photovoltaic size even more and the self-consumption rate can reach $80.9 \%$.

Cogenerators may also be part of a prosumer system, such as the one presented by Uchman [25]. The paper analyses a natural gas fuelled micro-cogenerator (micro-CHP) implemented in Poland, which can individually obtain a self-consumption rate of $28 \%$. If additional equipment is optimally added the level of prosumer self-consumption can be increased up to $58 \%$ (with a storage system) and up to $52 \%$ (with a photovoltaic production platform), or even up to $98 \%$ when integrating both solutions.

The next step after being a prosumer is indicated by Kuznetsova and Anjos [26]. The paper shows that under certain economic conditions such as the one in Ontario, Canada disconnecting from the grid might be even more convenient than being a prosumer by the year 2030. This can be attributed to the high electricity prices and the high share of fixed costs in the total electricity bill. The conclusion is even more surprising considering the high latitudes (up to $56.5^{\circ}$ ) and relatively low radiation profiles specific to Ontario.

Taking the example from other European Member States, Romania introduced in 2018 an amendment to the national law 220/2008 by including the Prosumer concept that allows the investors in grid-connected photovoltaic systems with a capacity up to $27 \mathrm{kWp}$ to receive a price for the electricity delivered to the grid. This price represents approximatively one third of the price paid when the electricity is consumed from the grid.

In this paper is presented a methodology to assess, based on locally measured weather data, the following: (1) the electrical energy production of a photovoltaic platform, (2) the electrical energy consumption of a geothermal heat pump system used for space heating in a building and (3) the self-consumption of the photovoltaic platform energy output by the heat pump systems. The methodology is applied and validated for a case study, a Solar House located in Brasov, Romania, for which experimental data measured during an entire year (2020) are used. Based on the results obtained through this methodology, solutions to increase the self-consumption are discussed.

\section{Methodology}

To assess the electrical energy self-consumption of a photovoltaic/geothermal heat pump a transient simulation software (e.g., Trnsys, EnergyPlus, DOE etc.) is necessary. In this paper, a methodology with four steps based on Trnsys 17 is further presented.

\subsection{Site Weather Data}

The weather data required in Trnsys17 consists of the following set of parameters: global horizontal solar irradiance, direct solar irradiance, outdoor air temperature and relative humidity, wind speed and direction, precipitable water. Usual weather stations 
provide these parameters. If diffuse horizontal solar irradiance is measured instead of direct solar irradiance, the latter is calculated using:

$$
B=B_{h} \sin \alpha\left[\mathrm{W} / \mathrm{m}^{2}\right],
$$

where:

$B_{h}$ is the direct horizontal solar irradiance calculated based on the measured global$\left(G_{h}\right)$ and diffuse- $\left(D_{h}\right)$ horizontal solar irradiance using:

$$
B_{h}=G_{h}-D_{h}\left[\mathrm{~W} / \mathrm{m}^{2}\right],
$$

$\alpha$ is the solar altitude angle [7] calculated based on the declination angle $(\delta)$, hour angle $(\omega)$ and site latitude $(\varphi)$ using:

$$
\alpha=\arcsin (\sin \delta \cdot \sin \varphi+\cos \delta \cdot \cos \varphi \cdot \cos \omega)\left[\left[^{\circ}\right] .\right.
$$

The declination angle [7] depends only on the number of the day $(N)$ in the year and is calculated using:

$$
\delta=23.45 \cdot \sin (360 \cdot(N-80) / 365)\left[^{\circ}\right] .
$$

The hour angle is a linear function of the solar time $\left(t_{s}\right)$ expressed in hours and is calculated using:

$$
\omega=15 \cdot\left(12-t_{s}\right)\left[{ }^{\circ}\right] .
$$

\subsection{Numerical Simulation of the Building Energy Demand}

To numerically simulate the building's thermal and electrical energy demand transient software must be used (e.g., Trnsys, Energy Plus, DOE etc.). In this paper, based on Trnsys17 Simulation Studio a 3D MultiZone Building project is developed (Figure 1). This numerical simulation is based on the characteristics of the site and of the building. The site characteristics are represented by the locally measured weather data. A Type 15-2 component is used in Trnsys17 to import the weather data. Recent weather data is recommended to be used. In their absence, multiannual averaged data provided by specialized databases (e.g., Meteonorm, NASA, SODA) may be used. In this case, differences between measured and multiannual averaged data may occur, distorting the error between simulation and experimental results. The building's characteristics refer the building envelope (slabs, walls, windows and roofs) in terms of geometry, orientation and thermal characteristics of the embedded materials. These building characteristics are transferred into a Type 56 component. Further on, Equation Cards components are used to calculate the azimuth angles of the exterior walls, windows and roof, the shading and the received solar irradiance. The functionality of the lighting system is simulated using a component Type 2d. Online plotter components Type 65a are used to display (while the simulation is progressing) and to export (to a user defined external file) the selected system variables: the received solar irradiance; the indoor and outdoor air temperatures; the energy loads. Type 24 components are used to integrate the thermal and electrical energy loads into monthly energy demand.

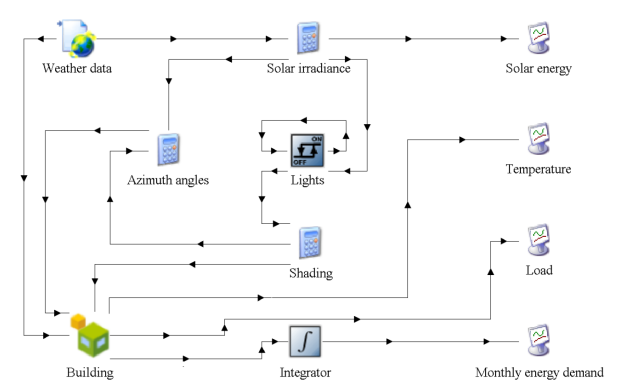

Figure 1. Trnsys17 model used for the evaluation of the energy demand of the building [27]. 


\subsection{Numerical Simulation of the Photovoltaic Platform Output}

To numerically simulate the photovoltaic platform output a Type $194 \mathrm{~b}$ component is used for the photovoltaic platform and an online plotter component Type 65a is used to display and plot the hourly and monthly photovoltaic electrical energy output (Figure 2).

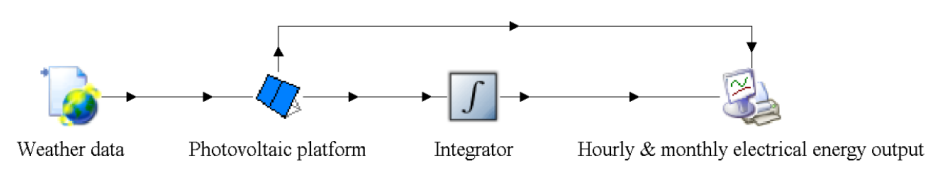

Figure 2. Trnsys17 model used for the evaluation of the photovoltaic platform energy output [27].

\subsection{Assessment of the Electrical Energy Self-Consumption}

Based on the results obtained through numerical simulations, to evaluate how much of the electrical energy demand of the geothermal heat pump system $\left(E_{H P}\right)$ is covered over a period of time by the electrical energy output of the photovoltaic platform $\left(E_{P V}\right)$, without considering the matching between the production and consumption periods, the coverage degree is calculated using:

$$
C D=E_{P V} / E_{\mathrm{HP}} \cdot 100[\%]
$$

To assess the amount of the electrical energy consumed by the geothermal heat pump system $\left(E_{H P i}\right)$ directly covered by the photovoltaic platform $\left(E_{P V i}\right)$ over a time period $t$, the self-consumption is evaluated using:

$$
S C=\frac{\sum_{i=0}^{t} E_{S C i}}{\sum_{i=0}^{t} E_{P V i}} \cdot 100[\%]
$$

where $E_{S C i}$ is the self-consumed energy in an hour (i) calculated using:

$$
E_{S C i}=\left\{\begin{array}{ll}
E_{P V i}, & \text { if } E_{P V i}<E_{H P i} \\
E_{H P i}, & \text { if } E_{P V i}>E_{H P i}
\end{array}[\mathrm{kWh}] .\right.
$$

\section{Case Study}

An existing renewable based energy mix delivering both thermal and electrical energy for the Solar House located on the Colina Hill Campus of the Transilvania University of Brasov, Romania (Figure 3) is considered as case study in this paper. The Solar House is a building with two floors, used in the educational process of the students.

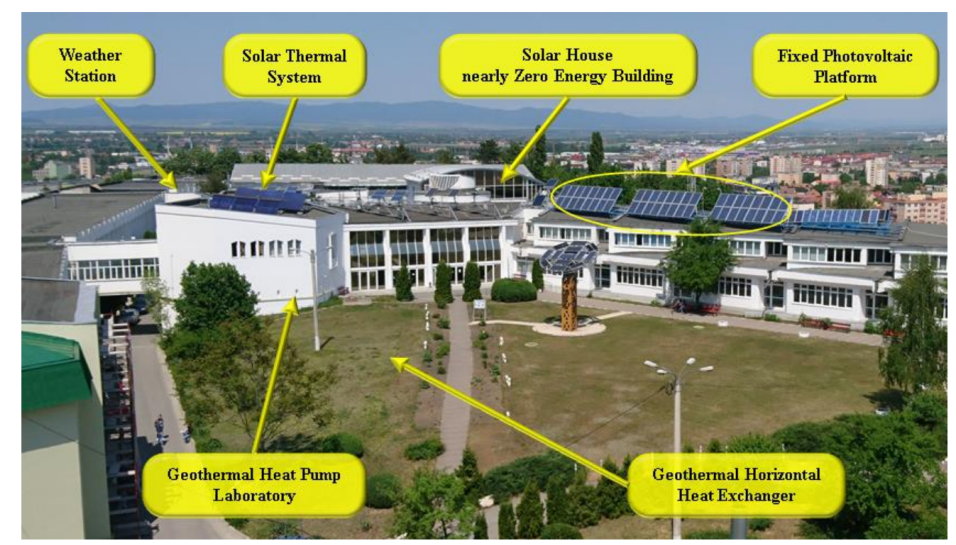

Figure 3. The Solar House and the renewable based energy mix installed on the Colina Hill Campus of the Transilvania University of Brasov, Romania.

This entire infrastructure serves as laboratories for the students enrolled in the B.Sc. programme study Renewable Energy Systems Engineering and in the M.Sc. programme 
study Sustainable Product Design and Environment Protection, as well as 1:1 testing rigs for research activities in the Renewable Energy Systems and Recycling Research Center.

The largest share of the Solar House energy demand is covered by a ground coupled heat pump (Figure 4). It has an installed capacity of $10.8 \mathrm{~kW}$ and it extracts the geothermal energy through a horizontal geothermal heat exchanger with an average depth of $1.7 \mathrm{~m}$ and a surface of $600 \mathrm{~m}^{2}$. The heat pump provides $98 \%$ of the thermal energy required for space heating in the Solar House [28]. The warm water produced by the heat pump is supplied to a storage tank with a capacity of $120 \mathrm{~L}$ wherefrom it is distributed in the low-temperature (limited to $25 \ldots 35^{\circ} \mathrm{C}$ ) underfloor heating system of the Solar House. The heat pump also contributes to the domestic hot water (DHW) preparation when the solar energy is not enough for the solar thermal system to cover it entirely.

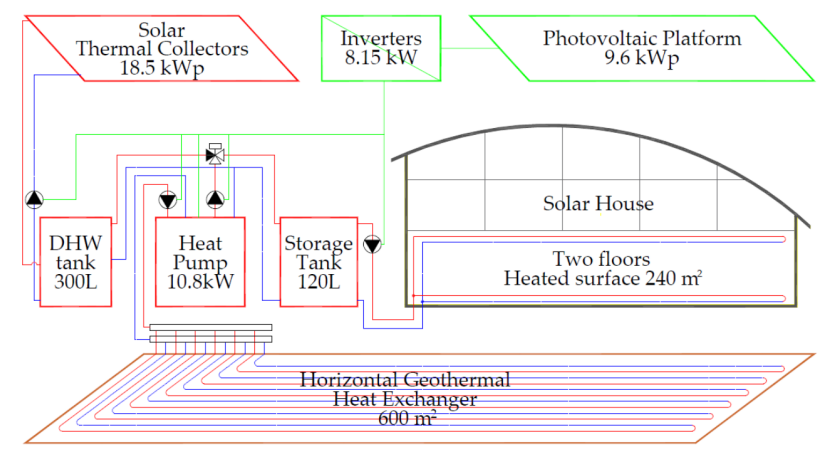

Figure 4. The connections between the components of the renewable energy systems supplying thermal and electrical energy to the Solar House.

The solar thermal system consists of six flat plate solar thermal collectors each one with a nominal thermal power of $1.88 \mathrm{~kW}$ and three evacuated tube solar thermal collectors each one with a nominal thermal power of $2.41 \mathrm{~kW}$. The solar thermal collectors are installed on the rooftop of a nearby building at a tilt angle of $42^{\circ}$ yearly optimized to maximize the thermal energy output during the periods with activity in the campus. This solar thermal system was designed to provide domestic hot water mainly for the locker rooms of a nearby Sport Hall [29].

The yearly electrical energy required by the Solar House, including the heat pump system, is partly covered by a $9.6 \mathrm{kWp}$ fixed photovoltaic platform [28]. This photovoltaic platform is grid connected and the electrical energy not used by the Solar House is distributed to the neighbouring buildings. The fixed photovoltaic platform is tilted at $48^{\circ}$ and consists of 48 polycrystalline silicon photovoltaic modules (type Energy Solutions, model ES200W) with a power of $200 \mathrm{Wp}$ each. The characteristics of the photovoltaic modules are presented in Table 1.

Table 1. Characteristics of the photovoltaic modules [30].

\begin{tabular}{ccc}
\hline Name & Unit & Value \\
\hline Maximum power & $\mathrm{W}$ & 203.4 \\
Module voltage at maximum power point and reference conditions & $\mathrm{V}$ & 26.9 \\
Module current at maximum power point and reference conditions & $\mathrm{A}$ & 7.5 \\
Module open-circuit voltage at reference conditions & $\mathrm{V}$ & 35.9 \\
Module short-circuit current at reference conditions & $\mathrm{A}$ & 8.0 \\
Temperature coefficient of open-circuit voltage at reference conditions & $\mathrm{V} / \mathrm{K}$ & -0.079 \\
Temperature coefficient of short-circuit current at reference conditions & & 0.02 \\
Number of cells wired in series & & 30 \\
Module area & $\mathrm{m}^{2}$ & 1.552 \\
Reference temperature & ${ }^{\circ} \mathrm{C}$ & 25 \\
Reference insolation & $\mathrm{W} / \mathrm{m}^{2}$ & 1000 \\
\hline
\end{tabular}


The fixed photovoltaic platform is connected to the local grid using three SMA SunnyBoy inverters (two SB 3300 and one SB 1700). Each of the two SB 3300 inverters has a nominal power of $3300 \mathrm{~W}$ and converts the energy from two parallel strings of 10 photovoltaic modules. A string of 8 photovoltaic modules is connected to the SB 1700 inverter with a nominal power $1550 \mathrm{~W}$. The monitoring system of the photovoltaic platform relies on a SMA Sunny Control device connected to SMA Sunny Portal [31]. The energy production data from each inverter is considered in the paper for a time interval between January and December 2020.

The meteorological parameters are locally measured using a Delta-T weather station consisting of accurate sensors presented in Table 2. The continuously monitored data is averaged and temporarily saved in a DL2e data logger (every minute for solar irradiance and every $10 \mathrm{~min}$ for the other parameters) and further stored in a database on a local computer.

Table 2. Characteristics of the weather station monitoring devices.

\begin{tabular}{ccc}
\hline Measured Parameters & Sensor & Accuracy \\
\hline Air temperature and the relative humidity & RHT2 probe & $\pm 0.1^{\circ} \mathrm{C}, 2 \% \mathrm{RH}$ \\
Horizontal global and diffuse solar irradiance & SPN1 pyranometer & $\pm 5 \%$. \\
Wind speed & AN4 anemometer & $\pm 0.5 \mathrm{~m} / \mathrm{s}$ \\
Wind direction & WD4 wind wane & $\pm 2 \%$ \\
Precipitable water amount & RG2 rain gauge & $\pm 2 \%$ \\
\hline
\end{tabular}

Further on, Trnsys3D plug-in for Google Sketchup adapted for Trnsys17 is used to create the 3D model of the Solar House. This 3D model is presented in Figure 5 where the South-Eastern and South-Western facades of the Solar House are shown. The Solar House has two floors, the first one accommodates a laboratory for solar thermal and geothermal systems and the second a multifunctional room used for classes, meetings etc. The Solar House is modelled as a Multizone building, considering one zone for the laboratory situated at the first floor, a second zone for the multifunctional room situated at the second floor and a third zone for the stair case. Large windows and curtain walls are installed to passively exploit the solar energy during the cold season. The shape of the Solar House was designed to enhance the natural ventilation and to reduce its energy demand. The main geometrical characteristics of the Solar House are presented in Table 3.

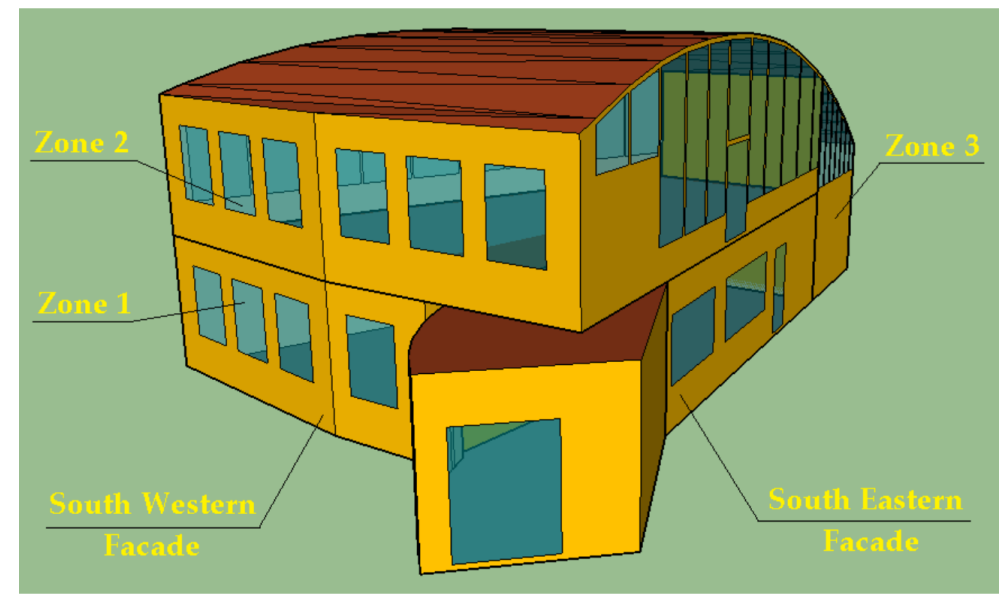

Figure 5. The 3D model of the Solar Hours created in Google Sketchup.

The 3D model of the Solar House was imported in TRNBuild where general information related to the building's implementation site (hemisphere, orientation) and basic properties (such as air properties, heat transfer coefficients etc.) were added. Further on, the characteristics of the building's envelope were defined (the layers and their properties for each building component). The thermal resistance of the building elements is presented in Table 4. 
Table 3. Geometrical characteristics of the Solar House.

\begin{tabular}{cccccc}
\hline Name & Unit & First Floor & Second Floor & Stairs & Total \\
\hline Floor surface & $\mathrm{m}^{2}$ & 101.50 & 96.00 & 34.50 & 232.00 \\
Height & $\mathrm{m}$ & 2.45 & 3.55 & 2.45 & \\
Volume & $\mathrm{m}^{3}$ & 248.68 & 340.80 & 84.52 & 674.00 \\
Exterior opaque walls & $\mathrm{m}^{2}$ & 102.13 & 30.42 & 5.28 & 137.83 \\
Exterior windows and curtain walls & $\mathrm{m}^{2}$ & 37.26 & 106.20 & 24.43 & 167.89 \\
Rooftop & $\mathrm{m}^{2}$ & & 96.00 & 18.00 & 114.00 \\
Window to Wall ratio & $\mathrm{m}^{2} / \mathrm{m}^{2}$ & 0.36 & 3.49 & 4.63 & 1.22 \\
Window to Floor ratio & $\mathrm{m}^{2} / \mathrm{m}^{2}$ & 0.37 & 1.11 & 0.71 & 0.72 \\
Shape factor & $\mathrm{m}^{2} / \mathrm{m}^{3}$ & 0.97 & 0.96 & 0.97 & 0.97 \\
\hline
\end{tabular}

Table 4. Thermal resistance of the building elements [28].

\begin{tabular}{ccc}
\hline Name & Unit & Value \\
\hline Floor & $\mathrm{m}^{2} \mathrm{~K} / \mathrm{W}$ & 2.446 \\
Exterior opaque walls & $\mathrm{m}^{2} \mathrm{~K} / \mathrm{W}$ & 3.270 \\
Exterior windows and curtain & $\mathrm{m}^{2} \mathrm{~K} / \mathrm{W}$ & 0.331 \\
walls & $\mathrm{m}^{2} \mathrm{~K} / \mathrm{W}$ & 2.190 \\
Rooftop &
\end{tabular}

According to the specific activities scheduled in the Solar House, the regime data for each zone (schedule, infiltration, heating, gains and initial values) was set as shown in Table 5. The regime data is implemented in each zone of the building considering that in each weekday an average number of 20 occupants are using the Solar House between 08:00 and 20:00. Ventilation is not required, as the infiltration air change rate is covering the required fresh air. Cooling is not evaluated due to the specific climate of the implementation site (mountain area with rather cold summers) and reduced activity volume/holiday between 15 of July and September 15 of September.

Table 5. Regime data for each zone.

\begin{tabular}{|c|c|c|}
\hline Name & Unit & Value \\
\hline \multicolumn{3}{|l|}{ Schedule } \\
\hline \multicolumn{3}{|l|}{ Weekdays } \\
\hline from 00:00 to $08: 00$ & & on-reduced regime \\
\hline from $08: 00$ to $20: 00$ & & on-normal regime \\
\hline from 20:00 to $00: 00$ & & on-reduced regime \\
\hline \multicolumn{3}{|l|}{ Weekend } \\
\hline from 00:00 to $24: 00$ & & on-reduced regime \\
\hline Infiltration air change rate & $1 / h$ & 0.5 \\
\hline \multicolumn{3}{|l|}{ Heating } \\
\hline set point temperature & ${ }^{\circ} \mathrm{C}$ & 20 (normal)/18 (reduced) \\
\hline power & $\mathrm{kJ} / \mathrm{h}$ & unlimited \\
\hline humidification & $\%$ & off \\
\hline \multicolumn{3}{|l|}{ Gains } \\
\hline number of occupants per building unit & persons & 20 \\
\hline degree of activity & & seated, light work \\
\hline rates of heat gain from occupants & W & 150 \\
\hline rates of heat gain from appliances & W & 230 \\
\hline rates of heat gain from artificial lighting & $\mathrm{W} / \mathrm{m}^{2}$ & 5 \\
\hline convective part of artificial lighting & $\%$ & 10 \\
\hline turn light $\mathrm{ON}$ if horizontal irradiance is lower than & $\mathrm{W} / \mathrm{m}^{2}$ & 120 \\
\hline turn light OFF if horizontal irradiance is higher than & $\mathrm{W} / \mathrm{m}^{2}$ & 200 \\
\hline \multicolumn{3}{|l|}{ Initial values } \\
\hline initial zone temperature & ${ }^{\circ} \mathrm{C}$ & 20 \\
\hline initial relative humidity & $\%$ & 50 \\
\hline
\end{tabular}




\section{Results}

The results obtained through numerical simulation based on the methodology presented in Section 2 for the case study analysed in Section 3 are further presented.

\subsection{Site Weather Data}

The global solar irradiance locally measured in 2020 is firstly compared with the values obtained from Meteonorm and Homer and the monthly variation is presented in Figure 6. In terms of yearly global solar energy received in the horizontal plane, similar values (1364 and $1370 \mathrm{kWh} / \mathrm{m}^{2}$ ) were obtained from local measurements and Meteonorm while Homer provided a lower value $\left(1207 \mathrm{kWh} / \mathrm{m}^{2}\right)$.

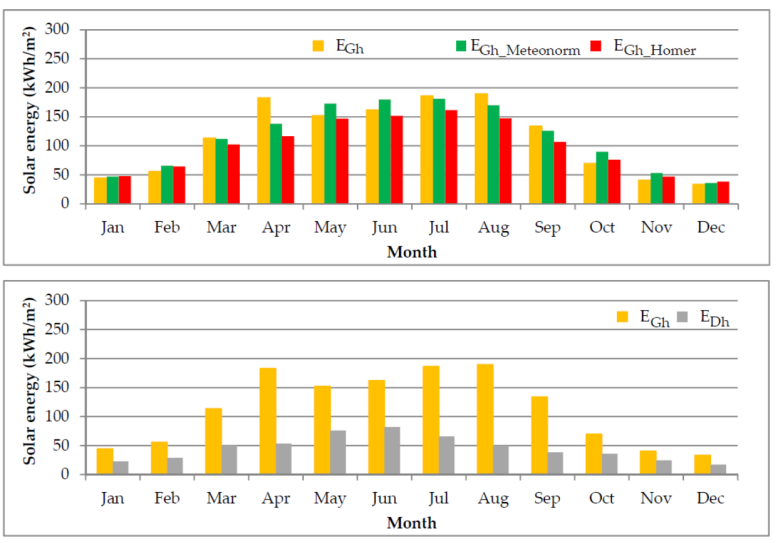

Figure 6. Monthly solar energy measured in the horizontal plane in Brasov $2020\left(\mathrm{E}_{\mathrm{Gh}}, \mathrm{E}_{\mathrm{Dh}}\right)$ and provided by databases ( $\mathrm{E}_{\mathrm{Gh} \_ \text {Meteonorm }}$ and $\left.\mathrm{E}_{\mathrm{Gh} \_ \text {Homer }}\right)$.

The measured global horizontal solar energy ranges between a minimum value of $33.57 \mathrm{kWh} / \mathrm{m}^{2}$ obtained in December and a maximum value of $189.50 \mathrm{kWh} / \mathrm{m}^{2}$ resulted in August. The values obtained in May, June and July are lower than expected for summer months and are caused by the low number of clear days. The minimum value of the monthly diffuse horizontal solar energy is obtained also in December $\left(17.25 \mathrm{kWh} / \mathrm{m}^{2}\right)$ while the maximum results in June $\left(82.13 \mathrm{kWh} / \mathrm{m}^{2}\right)$. When analysing the months of May and June, the amount of the monthly diffuse horizontal solar energy are 50 and $51 \%$, respectively of the global ones $\left(152\right.$ and $\left.162 \mathrm{kWh} / \mathrm{m}^{2}\right)$. Thus, the energy output of the photovoltaic platform, mainly relying on the direct solar energy, is expected to be lower in these months than in April, July and August.

Further on, using Equations (1)-(5) the direct solar irradiance required in Trnsys17 is evaluated based on the measured global- and diffuse- horizontal solar irradiance. The direct solar energy $\left(E_{B}\right)$ obtained in 2020 is $1644 \mathrm{kWh} / \mathrm{m}^{2}$, two time higher than the direct horizontal solar energy $\left(\mathrm{E}_{\mathrm{Bh}}\right) 819 \mathrm{kWh} / \mathrm{m}^{2}$. The monthly distribution of the direct horizontaland direct- solar energy obtained based on the measured values in Brasov in 2020 is plotted in Figure 7. The highest monthly values resulted in August $\left(139.8 \mathrm{kWh} / \mathrm{m}^{2}\right)$ and April $\left(262.95 \mathrm{kWh} / \mathrm{m}^{2}\right)$ for direct horizontal- and direct- solar energy, respectively while the minimum values were both obtained in November, 16.02 and $40.30 \mathrm{kWh} / \mathrm{m}^{2}$, respectively.

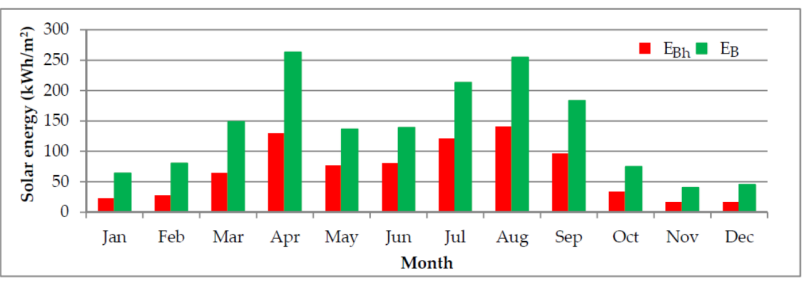

Figure 7. Monthly direct horizontal- and direct- solar energy calculated based on the on-site measured values in Brasov 2020. 
Another factor strongly influencing both thermal energy demand of the Solar House and the power output of the photovoltaic system is the outdoor air temperature. After processing its measured values during 2020 a monthly distribution is obtained (Figure 8).

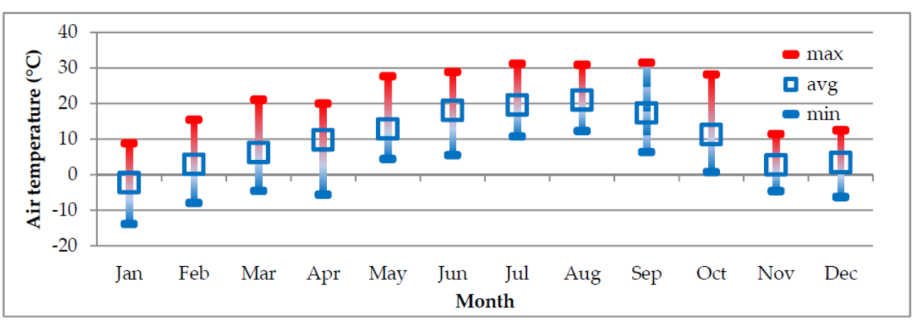

Figure 8. Monthly variation of the outdoor air temperature measured in Brasov 2020.

The lowest air temperature $\left(-13.9^{\circ} \mathrm{C}\right)$ occurred in January, month also characterized by the lowest average outdoor air temperature $\left(-2.3^{\circ} \mathrm{C}\right)$. In Romania, the reference temperature establishing the length of the heating period is $12{ }^{\circ} \mathrm{C}$. The monthly average temperatures drop below this limit in seven months in 2020, between January and April and from October till December. Even the month of May has a low monthly average temperature of $12.9^{\circ} \mathrm{C}$, partly including it in the heating season. Maximum temperatures above $30^{\circ} \mathrm{C}$ were registered in July $\left(31.2^{\circ} \mathrm{C}\right)$, August $\left(30.9^{\circ} \mathrm{C}\right)$ and September $\left(31.5^{\circ} \mathrm{C}\right)$. Therefore, it is expected that the thermal energy demand of the Solar House will be mainly represented by the energy required for heating rather than that for cooling.

The locally measured weather data is hourly averaged and imported in Trnsys17. The hourly variation of the outdoor air temperature (Ta) and the global horizontal solar irradiance (Gh) is plotted in Figure 9.

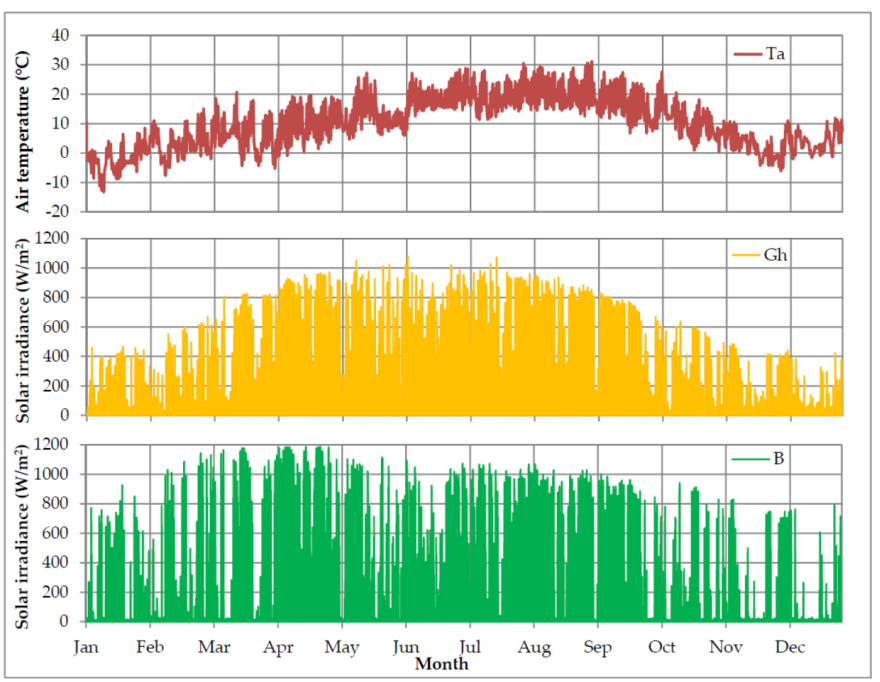

Figure 9. Hourly outdoor air temperature (Ta), global horizontal solar irradiance (Gh) and direct solar irradiance (B) imported in Trnsys17 based on the on-site measured values in Brasov in 2020.

\subsection{Numerical Simulation of the Building Energy Demand}

Further on, numerical simulation is performed in Trnsys17 to evaluate the thermal and electrical energy demand of the Solar House in accordance with the regime data established in methodology.

A yearly thermal energy demand of $47,097 \mathrm{kWh}$ resulted. The hourly variation of the thermal power required for heating of the Solar House is plotted in Figure 10. The thermal power reaches a maximum of $21.99 \mathrm{~kW}$ in January, corresponding to the minimum value of the outdoor air temperature of $-13.85^{\circ} \mathrm{C}$. The average value of the thermal power during the entire heating period resulted $9.67 \mathrm{~kW}$. 


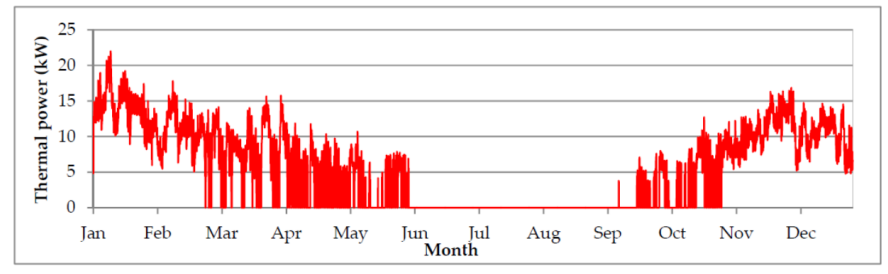

Figure 10. The hourly variation of the thermal power required by the Solar House.

The yearly electrical energy demand of the geothermal heat pump used for space heating in the Solar House is 14,323 kWh. Figure 11 shows the numerical simulation results of the hourly electrical power consumed by the geothermal heat pump used for space heating in the Solar House. The maximum value resulted also in January $(8.66 \mathrm{~kW})$. The average value of the electrical power during the entire heating period is $2.94 \mathrm{~kW}$.

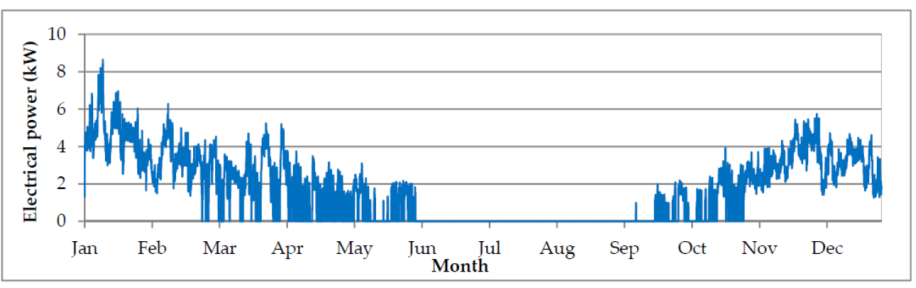

Figure 11. The hourly variation of the electrical power required by the geothermal heat pump used for space heating in the Solar House.

\subsection{Numerical Simulation of the Photovoltaic Platform Output}

The next step in the numerical simulation using Trnsys17 consist of the evaluation of the electrical energy output of the photovoltaic platform of $9.6 \mathrm{kWp}$ installed on a rooftop nearby Solar House. The hourly variation of the electrical power is plotted in Figure 12. The maximum electrical power $(7.39 \mathrm{~kW})$ was obtained in a clear sky day of March when the noon solar altitude angle $\left(45^{\circ}\right)$ closely matched the tilt angle $\left(45^{\circ}\right)$ of the photovoltaic platform and the low outdoor air temperature $\left(9.5^{\circ} \mathrm{C}\right)$ positively affected the photovoltaic conversion efficiency.

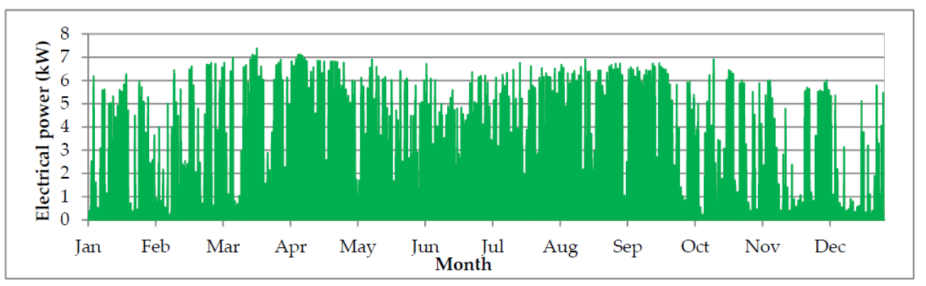

Figure 12. The simulated hourly electrical power output of the $9.6 \mathrm{kWp}$ photovoltaic platform.

\subsection{Assessment of the Electrical Energy Self-Consumption}

The yearly electrical energy output of the photovoltaic platform reaches $9975 \mathrm{kWh}$ covering on a yearly basis $70 \%$ of the entire electrical energy demand of the geothermal system $(14,323 \mathrm{kWh})$. However, this coverage may be considered only when the grid administrator allows a 1:1 compensation of the electrical energy delivered to the grid with that consumed from the grid (same price is applied for both, produced and consumed electrical energy). When this does not happen, the coverage degree must be analysed at a lower time scale. When comparing the monthly values of the consumed $\left(\mathrm{E}_{\mathrm{HP}}\right)$ and produced $\left(\mathrm{E}_{\mathrm{PV}}\right)$ electrical energy (Figure 13), the mismatch between the consumption and production is more than obvious. The monthly coverage degree decreases to $16 \%$ in January. Between April and September, the photovoltaic platform produced a larger amount of electrical energy than that required by the geothermal heat pump. 


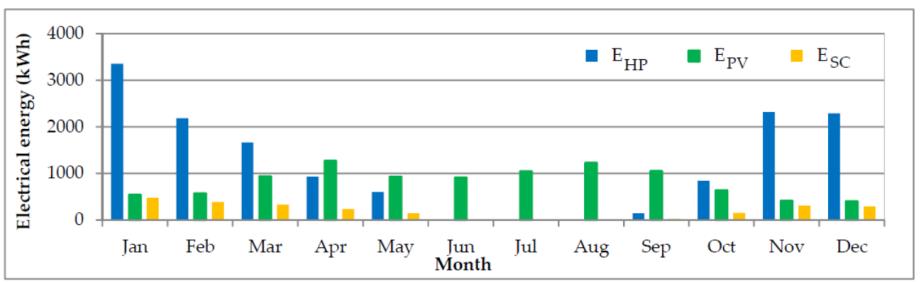

Figure 13. The monthly simulated electrical energy consumption of the geothermal heat pump ( $\left.\mathrm{E}_{\mathrm{HP}}\right)$, electrical energy output of the photovoltaic platform $\left(\mathrm{E}_{\mathrm{PV}}\right)$ and the electrical energy output of the photovoltaic platform directly consumed by the geothermal heat pump $\left(\mathrm{E}_{\mathrm{SC}}\right)$.

The monthly amount of the electrical energy produced by the photovoltaic platform directly used by the geothermal heat pump system $\left(E_{S C}\right)$ is also plotted in Figure 13. A yearly value of only $2352 \mathrm{kWh}$ resulted, corresponding to an annual self-consumption (SC) of $16 \%$. During the winter months (November-February), almost the entire electrical energy produced by the photovoltaic platform is directly used.

Further reducing the time scale to a day, the direct coverage degree is evaluated for sunny days in January and April through Trnsys simulations performed based on locally measured weather data. As shown in Figure 14 for 18 January 2020, the electrical power load of the heat pump system ranges between 2.53 and $5.75 \mathrm{~kW}$, and has a daily average value of $3.88 \mathrm{~kW}$ corresponding to a daily electrical energy demand of $93.14 \mathrm{kWh}$.

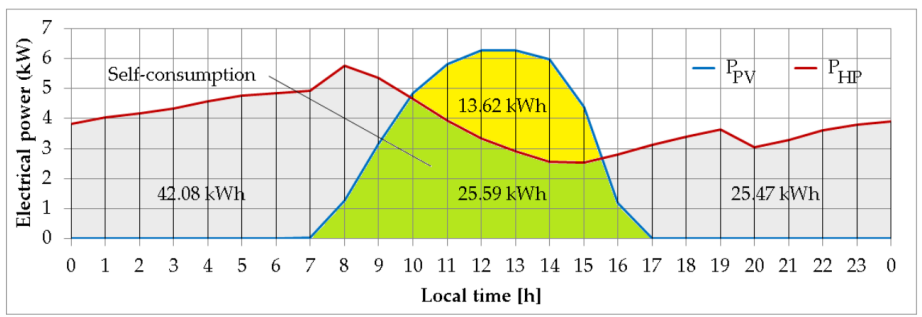

Figure 14. Simulated hourly the electrical power consumption of the geothermal heat pump $\left(\mathrm{P}_{\mathrm{HP}}\right)$ and of the electrical power production $\left(\mathrm{P}_{\mathrm{PV}}\right)$ of the photovoltaic platform (18 January 2020).

The photovoltaic platform reaches a maximum output of $6.27 \mathrm{~kW}$ at noon producing a daily electrical energy of $39.21 \mathrm{kWh}$. From this value, $25.59 \mathrm{kWh}(65 \%)$ of the electrical energy production of the photovoltaic platform (the green area in Figure 14) is directly used by the geothermal heat pump, representing $27 \%$ from its daily electrical energy demand ( $93.14 \mathrm{kWh})$. To further increase the electrical energy self-consumption, the heat pump system could be operated during the day at a higher power to produce more thermal energy that must be stored. Thus, the night electrical energy consumption could be reduced with maximum $13.62 \mathrm{kWh}(100 \%$ self-consumption) and the coverage degree of the electrical energy demand of the heat pump increases to $42 \%$.

During a sunny day in April (27 April 2020), the electrical power load of the heat pump system ranges between 0 and $2.68 \mathrm{~kW}$, and has an average value of $1.74 \mathrm{~kW}$ over the heating period corresponding to a daily electrical energy demand of $26.16 \mathrm{kWh}$ (Figure 15). Due to increased length of the daytime and maximum power output at noon $(6.76 \mathrm{~kW})$, the photovoltaic platform produced $51.07 \mathrm{kWh}$ out of which only $11 \%(5.69 \mathrm{kWh})$ is directly used by the geothermal heat pump resulting a coverage degree of $22 \%$. During this kind of days, the storage of the thermal energy produced by the heat pump is mandatory to fully use the electrical energy available during the daytime. For the considered day, a storage capacity of 1000 litres of water would be necessary to be heated from $10^{\circ}$ to $50^{\circ} \mathrm{C}$.

Thus, the yearly coverage degree of $70 \%$ obtained in the case of 1:1 compensation with the grid represents an annual self-consumption of $16 \%$. This evaluation is very important in the cases when the electrical energy delivered to the grid is not paid by the grid owner, or the received price is significantly lower than the price paid for the energy consumed 
from the grid. The latter is the case in Romania, where the electrical energy consumed from the grid costs approximatively 0.13 euro $/ \mathrm{kWh}$ while the electrical energy delivered to the grid is paid with approximatively 0.04 euro $/ \mathrm{kWh}$. Thus, for the case study considered in the paper, from the yearly electrical energy provided by the $9.6 \mathrm{kWp}$ photovoltaic platform ( $9975 \mathrm{kWh}$ ), only $2352 \mathrm{kWh}$ can be considered as savings at a rate of $0.13 \mathrm{euro} / \mathrm{kWh}$ while for the difference of $7623 \mathrm{kWh}$ will be received the price of $0.04 \mathrm{euro} / \mathrm{kWh}$. Thus, the yearly savings result 610.64 euro. If the entire electrical energy is directly used, the yearly savings increases more than twice, at 1296.69 euro/year.

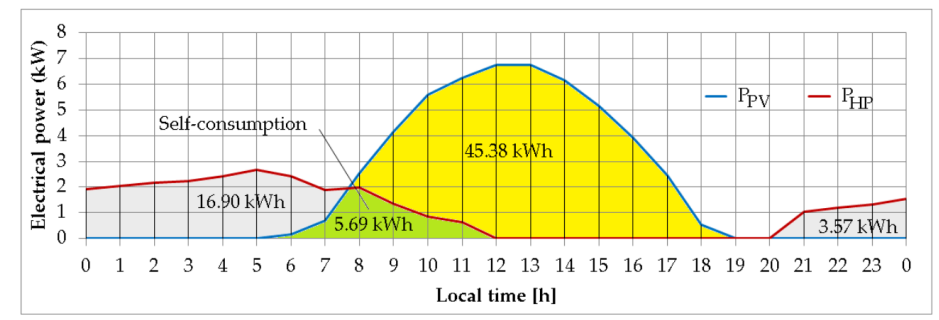

Figure 15. Simulated hourly the electrical power consumption of the geothermal heat pump $\left(\mathrm{P}_{\mathrm{HP}}\right)$ and of the electrical power production ( $\mathrm{P}_{\mathrm{PV}}$ ) of the photovoltaic platform (27 April 2020).

Solutions to increase the self-consumption may be further investigated (e.g., changing the tilt angle of the photovoltaic platform, storing the thermal and/or electrical energy, using the energy for other functionalities).

\section{Experimental Validation of the Electrical Energy Production and Consumption}

The results of the numerical simulations performed in Trnsys17 are further compared with experimental data from the monitoring systems of the Solar House for the photovoltaic platform (Figure 16) and geothermal heat pump (Figure 12). The electrical power consumed by the geothermal heat pump system and that produced by the $9.6 \mathrm{kWp}$ photovoltaic platform obtained through numerical simulations are further integrated into monthly electrical energy values.

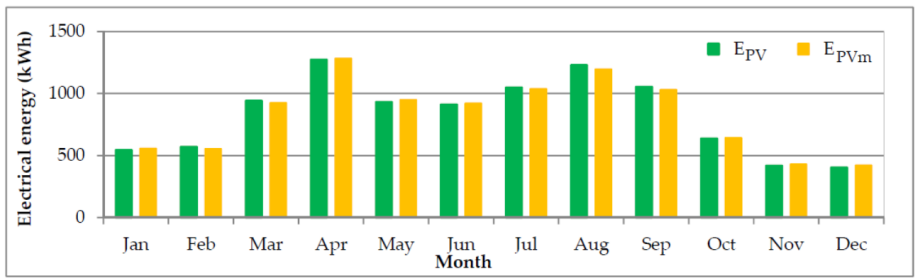

Figure 16. The monthly electrical energy output of the $9.6 \mathrm{kWp}$ photovoltaic platform obtained through Trnsys17 numerical simulations $\left(\mathrm{E}_{\mathrm{PV}}\right)$ and measured by the monitoring system $\left(\mathrm{E}_{\mathrm{PVm}}\right)$.

The yearly electrical energy output of the $9.6 \mathrm{kWp}$ photovoltaic platform obtained through numerical simulation $(9975 \mathrm{kWh})$ is slightly higher than the value measured in 2020 (9957 kWh). The monthly relative differences range between -4 and $+3 \%$ obtained in December and February, respectively (Figure 11). The monthly weather conditions (monthly averaged outdoor air temperature- $\mathrm{T}_{\mathrm{am}}$, and the solar energy monthly received in the plane of the photovoltaic platform- $\mathrm{E}_{\mathrm{Gn}}$ ) and relative differences between the monthly simulated and measured values of the photovoltaic platform electrical energy output $\left(\varepsilon_{\mathrm{PV}}\right)$ are comparatively presented in Table 6.

Table 6. Weather conditions and the relative differences of photovoltaic electrical energy output.

\begin{tabular}{ccccccccccccc}
\hline Parameter/Month & Jan & Feb & Mar & Apr & May & Jun & Jul & Aug & Sep & Oct & Nov & Dec \\
\hline $\mathrm{T}_{\mathrm{am}}\left({ }^{\circ} \mathrm{C}\right)$ & -2.2 & 2.9 & 6.2 & 9.8 & 12.8 & 18.0 & 19.6 & 20.9 & 17.3 & 11.2 & 2.7 & 3.4 \\
$\mathrm{E}_{\mathrm{Gn}}\left(\mathrm{kWh} / \mathrm{m}^{2}\right)$ & 82 & 87 & 146 & 200 & 142 & 139 & 162 & 192 & 164 & 97 & 62 & 60 \\
$\varepsilon_{\mathrm{PV}}(\%)$ & -2.3 & 3.2 & 1.8 & -0.8 & -1.9 & -0.9 & 1.2 & 2.7 & 2.2 & -0.7 & -2.8 & -4.3 \\
\hline
\end{tabular}


For the electrical energy consumption of the geothermal heat pump system (Figure 17), acceptable differences (lower than 10\%) are obtained for the winter months. Also, the yearly electrical energy consumption obtained through numerical simulation $(14,323 \mathrm{kWh})$ is only $6 \%$ lower than the yearly measured value $(15,174 \mathrm{kWh})$.

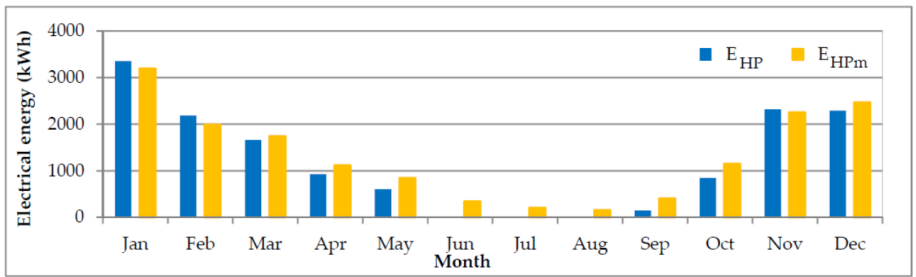

Figure 17. The monthly electrical energy consumption of the geothermal system obtained through Trnsys17 numerical simulations $\left(\mathrm{E}_{\mathrm{HP}}\right)$ and measured by the monitoring system $\left(\mathrm{E}_{\mathrm{HPm}}\right)$.

The values measured in June and July correspond to the electrical energy consumption during laboratory experiments performed in these months and the consumption of the monitoring system. In August, the measured value corresponds strictly to the consumption of the monitoring system. These values are not considered in the above validation process. In the following sections numerical simulations were used, with zero energy use for the heat pump during summer months.

Based on the good agreement found between the numerical simulations and measured values for both electrical energy consumed by the geothermal heat pump system and produced by the photovoltaic platform, the model developed in Trnsys can be considered experimentally validated and, further on, the results of the numerical simulations are presented.

\section{Discussions}

The results obtained in this paper are further compared with the results of the similar studies fund in literature and synthetized in Tables 7 and 8 . As shown in Table 7, there are different types of buildings evaluated in the literature (residential, commercial, office), while this paper addresses a building used in the higher education system. These studies were done in different locations, mainly in the northern and southern part of Europe. The simulations are usually done with Trnsys over a period of one year, based on weather data measured onsite or standard data. To the best of our knowledge, there are no studies including both numerical simulations and experimental validation. In our paper the numerical simulations through the proposed methodology are validated based on the experimental data recorded over a period of one year. The monthly errors between simulated and measured photovoltaic energy values range between -4 and $+3 \%$ with an annual error lower than $1 \%$. The electrical energy consumption of the heat pump obtained through numerical simulation is only $6 \%$ lower than the yearly measured value.

Table 7. Synthesis of the similar studies found in literature.

\begin{tabular}{|c|c|c|c|c|c|c|}
\hline \multirow{2}{*}{ Ref. } & \multirow{2}{*}{ Building Type } & \multirow{2}{*}{ Location } & \multicolumn{3}{|c|}{ Numerical Simulations } & \multirow{2}{*}{$\begin{array}{l}\text { Experimental } \\
\text { Testing }\end{array}$} \\
\hline & & & Period & Software & Input Weather Data & \\
\hline [8] & Single family residence & Texas, USA & no & no & no & 1 year \\
\hline [9] & Multifamily residential & Geneva, Switzerland & 1 year & Trnsys & onsite measured 2010 & no \\
\hline [10] & Residential & Pisa, Italy & no & no & no & 1 year \\
\hline [14] & Office & Mikkeli, Finland & 1 year & Trnsys & onsite measured2016 & no \\
\hline [16] & 16 dwellings & The Netherlands & no & no & no & 2 years \\
\hline [19] & single family houses & Finland & 1 year & IDA-ICE Trnsys & standard Finnish ref. year 2010 & no \\
\hline [24] & Residential building cluster & Borlänge, Sweden & 1 year & Trnsys & onsite measured hourly data & no \\
\hline This study & Educational & Brasov, Romania & 1 year & Trnsys & onsite measured 2020 & 1 year \\
\hline
\end{tabular}

The results of the papers from Table 7 are comparatively presented in Table 8 . These studies refer to the photovoltaic energy consumed by heat pumps (for space heating, 
domestic hot water and space cooling) and other functionalities in the buildings (appliances, electrical vehicle and community sharing). In our paper only the space heating with a heat pump is analysed.

Table 8. Synthesis of the results of similar studies found in literature.

\begin{tabular}{ccccc}
\hline Ref. & Functionality & $\begin{array}{c}\text { Yearly Coverage } \\
\text { Degree, } \%\end{array}$ & Selfconsumption, \% & $\begin{array}{c}\text { Evaluation } \\
\text { Frequency }\end{array}$ \\
\hline$[8]$ & SH, SC & & 54.6 & monthly \\
daily \\
{$[9]$} & DHW, SH & & $57-96$ & hourly \\
{$[9]$} & DHW, SH & & $33-59$ & daily \\
{$[10]$} & A, DHW, SH & 66.9 & $31.5-35.7$ in winter & daily \\
{$[10]$} & A, DHW, SC & 66.9 & $96.6-100$ in summer & hourly \\
{$[14]$} & DHW, SH & & 15 & 15 min \\
{$[16]$} & DHW, SH & & 19 & hourly \\
{$[19]$} & A, DHW, SH & $49-100$ & $9-28$ & hourly \\
{$[24]$} & A, DHW, SH, CS & & 77 & hourly \\
{$[24]$} & A, DHW, SH, TS & & 79.4 & hourly \\
{$[24]$} & A, DHW, SH, EV & & 80.9 & 16 \\
This study & SH & 70 & & \\
\hline
\end{tabular}

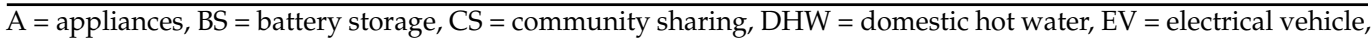
$\mathrm{SC}=$ space cooling, $\mathrm{SH}=$ space heating, $\mathrm{TS}=$ thermal storage.

Two papers, $[10,19]$, present results related to the yearly coverage degree ranging between 49 and $100 \%$ according to the considered functionalities. In our paper, the yearly coverage degree for space heating is $70 \%$.

Related to self-consumption, our result (16\%) can be compared with papers performing only numerical simulations [14,19], and only experimental testing [16], for similar functionalities (SH and DHW) and similar evaluation frequencies (hourly or $15 \mathrm{~min}$ ).

Higher self-consumption values (between 77 and $81 \%$ ) resulted when the photovoltaic energy is also used for other functionalities.

\section{Conclusions}

A methodology to assess the self-consumption of the electrical energy output of a photovoltaic platform by a geothermal heat pump is proposed and experimentally validated in the paper.

The proposed methodology consists of four steps starting with the site weather data, numerical simulation of the building energy demand, numerical simulation of the photovoltaic platform output and the assessment of the self-consumption of the photovoltaic/geothermal heat pump system. It can be applied to any type of building.

The methodology was applied to a case study represented by a building used in the educational process of students (Solar House) equipped with a grid-connected photovoltaic platform supplying electrical energy to a geothermal heat pump.

The results of the numerical simulations show that the yearly electrical energy consumption of the heat pump system is covered $70 \%$ by the electrical energy output of the photovoltaic platform, but the self-consumption is only $16 \%$.

The error between the simulated and measured values resulted of $6 \%$ for the consumed energy and below $1 \%$ for the produced energy.

Author Contributions: Conceptualization, M.M. and I.V.; methodology, M.M.; software, M.M. and B.-G.B.; validation, M.M. and B.-G.B.; formal analysis, M.M. and B.-G.B.; investigation, M.M. and B.-G.B.; resources, I.V., M.M. and B.-G.B.; data curation, M.M. and B.-G.B.; writing-original draft preparation, M.M.; writing-review and editing, M.M. and B.-G.B.; visualization, M.M.; supervision, M.M. and I.V. All authors have read and agreed to the published version of the manuscript.

Funding: This research received no external funding.

Institutional Review Board Statement: Not applicable.

Informed Consent Statement: Not applicable. 


\section{Data Availability Statement: Not applicable.}

Conflicts of Interest: The authors declare no conflict of interest. There are not any funders having a role in the design of the study; in the collection, analyses, or interpretation of data; in the writing of the manuscript, or in the decision to publish the results.

\section{Nomenclature}

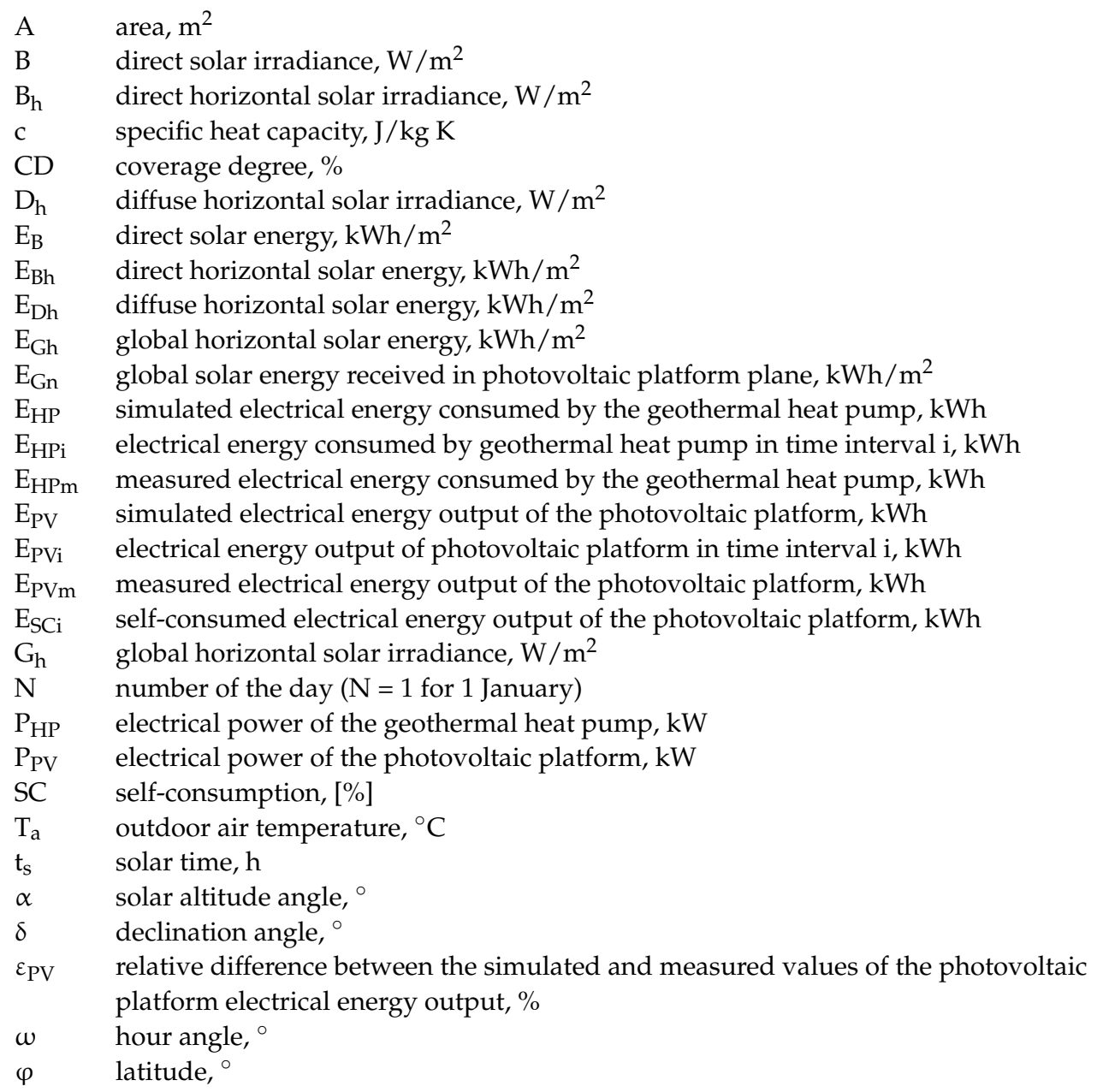

\section{References}

1. International Energy Agency. IEA World Energy Balances. 2020. Available online: https://www.iea.org/subscribe-to-dataservices/world-energy-balances-and-statistics (accessed on 15 February 2020).

2. International Energy Agency. IEA Renewables Information Database. 2020. Available online: https://www.iea.org/subscribe-todata-services / renewables-statistics (accessed on 15 February 2020).

3. International Renewable Energy Agency. Renewable Power Generation Costs in 2019; International Renewable Energy Agency: Abu Dhabi, United Arab Emirates, 2020; ISBN 978-92-9260-244-4.

4. Dewhurst, H.; Waldner, M.; Trabesinger, W. Assessing PPA Prices alongside LCOE; BloombergNEF: Zurich, Switzerland, 2021.

5. European Heat Pump Association. The European Heat Pump Market and Statistics Report 2020; EHPA: Brussels, Belgium, 2020.

6. European Commission. The European Green Deal, Communication from the Commission to the European Parliament, the European council, the Council, the European Economic and Social Committee and the Committee of the Regions; COM 640; European Commission: Brussels, Belgium, 2019.

7. Visa, I.; Duta, A.; Moldovan, M.; Burduhos, B.; Neagoe, M. Solar Energy Conversion Systems in the Built Environment; Springer, Green Energy and Technology, Springer Nature: Cham, Switzerland, 2020.

8. Kugle, S.; Green, S.; Haji-Sheikh, A.; Lou, A.Y.S. Performance of solar assisted heat pump systems in residential applications. Sol. Energy 1984, 32, 169-179. [CrossRef]

9. Fraga, C.; Hollmuller, P.; Schneider, S.; Lachal, B. Heat pump systems for multifamily buildings: Potential and constraints of several heat sources for diverse building demands. Appl. Energy 2018, 225, 1033-1053. [CrossRef]

10. Franco, A.; Fantozzi, F. Experimental analysis of a self-consumption strategy for residential building: The integration of PV system and geothermal heat pump. Renew. Energy 2016, 86, 1075-1085. [CrossRef] 
11. Nizetic, S.; Coko, D.; Marasovic, I. Experimental study on a hybrid energy system with small- and medium- scale applications for mild climates. Energy 2014, 75, 379-389. [CrossRef]

12. Nizetic, S.; Duic, N.; Papadopulos, A.M.; Tina, G.M.; Grubisic-Cabo, F. Energy efficiency evaluation of a hybrid energy system for building applications in a Mediterranean climate and its feasibility aspect. Energy 2015, 90, 1-9. [CrossRef]

13. Perkovic, L.; Leko, D.; Brettschneider, A.L.; Mikulcic, H.; Varbanov, S. Integration of Photovoltaic Electricity with Shallow Geothermal Systems for Residential Microgrids: Proof of Concept and Techno-Economic Analysis with RES2GEO Model. Energies 2021, 14, 1923. [CrossRef]

14. Reda, F.; Paiho, S.; Pasonen, R.; Helm, M.; Menhart, F.; Schex, R.; Laitinen, A. Comparison of solar assisted heat pump solutions for office building applications in Northern climate. Renew. Energy 2020, 147, 1392-1417. [CrossRef]

15. Thygesen, R.; Karlsson, B. Simulation of a proposed novel weather forecast control for ground source heat pumps as a mean to evaluate the feasibility of forecast controls' influence on the photovoltaic electricity self-consumption. Appl. Energy 2016, 164, 579-589. [CrossRef]

16. Litjens, G.; Worrell, E.; van Sark, W. Lowering greenhouse gas emissions in the built environment by combining ground source heat pumps, photovoltaics and battery storage. Energy Build. 2018, 180, 51-71. [CrossRef]

17. Facci, A.L.; Krastev, V.K.; Falcucci, G.; Ubertini, S. Smart integration of photovoltaic production, heat pump and thermal energy storage in residential applications. Sol. Energy 2019, 192, 133-143. [CrossRef]

18. Rinaldi, A.; Soini, M.C.; Streicher, K.; Patel, M.K.; Parra, D. Decarbonising heat with optimal PV and storage investments: A detailed sector coupling modelling framework with flexible heat pump operation. Appl. Energy 2021, 282, 116110. [CrossRef]

19. Hirvonen, J.; Kayo, G.; Hasan, A.; Siren, K. Zero energy level and economic potential of small-scale building-integrated PV with different heating systems in Nordic conditions. Appl. Energy 2016, 167, 255-269. [CrossRef]

20. Beck, T.; Kondziella, H.; Huard, G.; Bruckner, T. Optimal operation, configuration and sizing of generation and storage technologies for residential heat pump systems in the spotlight of self-consumption of photovoltaic electricity. Appl. Energy 2017, 188, 604-619. [CrossRef]

21. Metzger, M.; Szabo, A.; Bamberger, J. Control as a Key Technology for the Grid Integration of Renewables. IFAC Proc. Vol. 2011, 44, 14772-14777. [CrossRef]

22. Riveros, J.Z.; Kubli, M.; Ulli-Beer, S. Prosumer communities as strategic allies for electric utilities: Exploring future decentralization trends in Switzerland. Energy Res. Soc. Sci. 2019, 57, 101219. [CrossRef]

23. Kusakana, K. Optimal peer-to-peer energy management between grid-connected prosumers with battery storage and photovoltaic systems. J. Energy Storage 2020, 32, 101717. [CrossRef]

24. Huang, P.; Lovati, M.; Zhang, X.; Bales, C.; Hallbeck, S.; Becker, A.; Bergqvist, H.; Hedberg, J.; Maturi, L. Transforming a residential building cluster into electricity prosumers in Sweden: Optimal design of a coupled PV-heat pump-thermal storage-electric vehicle system. Appl. Energy 2019, 255, 113864. [CrossRef]

25. Uchman, W. The cost of increasing prosumer self-sufficiency. Appl. Therm. Eng. 2021, 186, 116361. [CrossRef]

26. Kuznetsova, E.; Anjos, M.F. Prosumers and energy pricing policies: When, where, and under which conditions will prosumers emerge? A case study for Ontario (Canada). Energy Policy 2021, 149, 111982. [CrossRef]

27. Klein, S.A.; Beckman, W.A.; Mitchell, J.W.; Duffie, J.A.; Duffie, N.A.; Freeman, T.L.; Mitchell, J.C.; Braun, J.E.; Evans, B.L.; Kummer, J.P.; et al. TRNSYS 17: A Transient System Simulation Program; Solar Energy Laboratory, University of Wisconsin: Madison, WI, USA, 2017.

28. Visa, I.; Moldovan, M.; Comsit, M.; Duta, A. Improving the renewable energy mix in a building toward the nearly zero energy status. Energy Build. 2014, 68, 72-78. [CrossRef]

29. Moldovan, M.; Visa, I.; Burduhos, B. Experimental Comparison of Flat Plate and Evacuated Tube Solar Thermal Collectors for Domestic Hot Water Preparation in Education Facilities. J. Sustain. Dev. Energy Water Environ. Syst. 2020, 8, 293-303. [CrossRef]

30. Energy Solutions. Technical Specifications of Photovoltaic Modules ES200W; Energy Solutions: Athens, Greece, 2008.

31. Burduhos, B.; Visa, I.; Neagoe, M.; Cretescu, N. Simulated vs. Produced Electrical Energy of a 9.6 kWp PV System Installed in a Temperate Mountain Climate. J. Sci. Arts 2020, 1, 215-224. 